\title{
RUSSIAN ANIMAL ART OF THE XIX-XX CENTURIES IN THE VIEWS ON THE WORLD OF FLORA AND FAUNA
}

Summary: The article dwells on views of artists-animalists of the XIX-XX centuries on the wildlife world. The worldview questions are considered as a factor of the value of the interconnection of human and wildlife world which is predetermined by the historical situation. The author underlines the indispensable role of the animal in the development of human civilization. So, this implies an ethical attitude towards nature as a unique value. It was also noted that the moral and ethical basis of this relationship, that became actual in the era of global change

\section{Introduction}

In the 20th century, due to a heightened perception of the world of wildlife, reasoning on the subject of relationship of human and animals became especially actual, what, in its turn, has led people to the pursuit of a deeper analysis of the heritage of animal artists. It's worth to pay attention to articles of V. A. Tikhanova [Tikhanova, 1990: 238], which are written in style of artistic and critical essays. Their importance is in the problems that are considered in them, which are closely tied up with the moral and ethical evaluation flowing out of the main meaning of painter-animalist's works. The author notes that among a variety of expressive means and techniques, which painters of the 20th century turn to, there is a conception of the wildlife protection that is correlated with tasks of the animalistic art at the modern step. The painter-animalist, V. Vatagin, was arguing on the same topic on the pages of his memoir «Memories. Animalist's notes» [Vatagin, 1980: 213], the base of which consists of materials of the previous edition, «The image of animal» [Vatagin, 1957: 170]. The work of Vatagin and a book of I. S. Efimov published in 1977, «About art and artists» [Efimov,1977: 323], include artistic and theo- and the crisis of the ecological situation, was contributing to the formation of ecological way of thinking as the reality of the New time. According to the artist-animalist's worldview, an animal looks beautiful, its behavior is expedient, that has a beneficial impact on human. The interconnection of artists' points of view and the way how they see the animalistic image from the position of humans of the New time are also considered in this article.

Keywords: domestic animals, ideology, nature, ecology

retical views of masters on the world of wildlife and the art of animalism, methods of work in sculpture and graphics. So, a clear statement of artists' views on the animal world and the art of its image (especially consecutive Vatagin's ones), allows us to reveal their system of values and ideals, which turned out to be very relevant in the era of setting global environmental problems.

Nowaday's researchers talks about new moral standards regarding wildlife. In the ancient cultures animal was always included into the field of the myth, folklore, human's thoughts and dreams, was a kind of symbol, what was reflected at the level of the collective and individual mind [Caspari Elizabeth, 2003: 350], but in the era of technological revolutions there was a kind of tension between people and animals, which sometimes manifested in a misunderstanding of the very essence of nature [Peterson Anna 2013: 236]. Samantha Hurn [Samantha Hurn 2012: 266] talks about the need of development of the eco tourism nowadays.

In the aspect of reasoning, the relevance of the article is determined by the need to study the ideological principles of the work of animal artists, first of all, being the base of the creative intention of the 


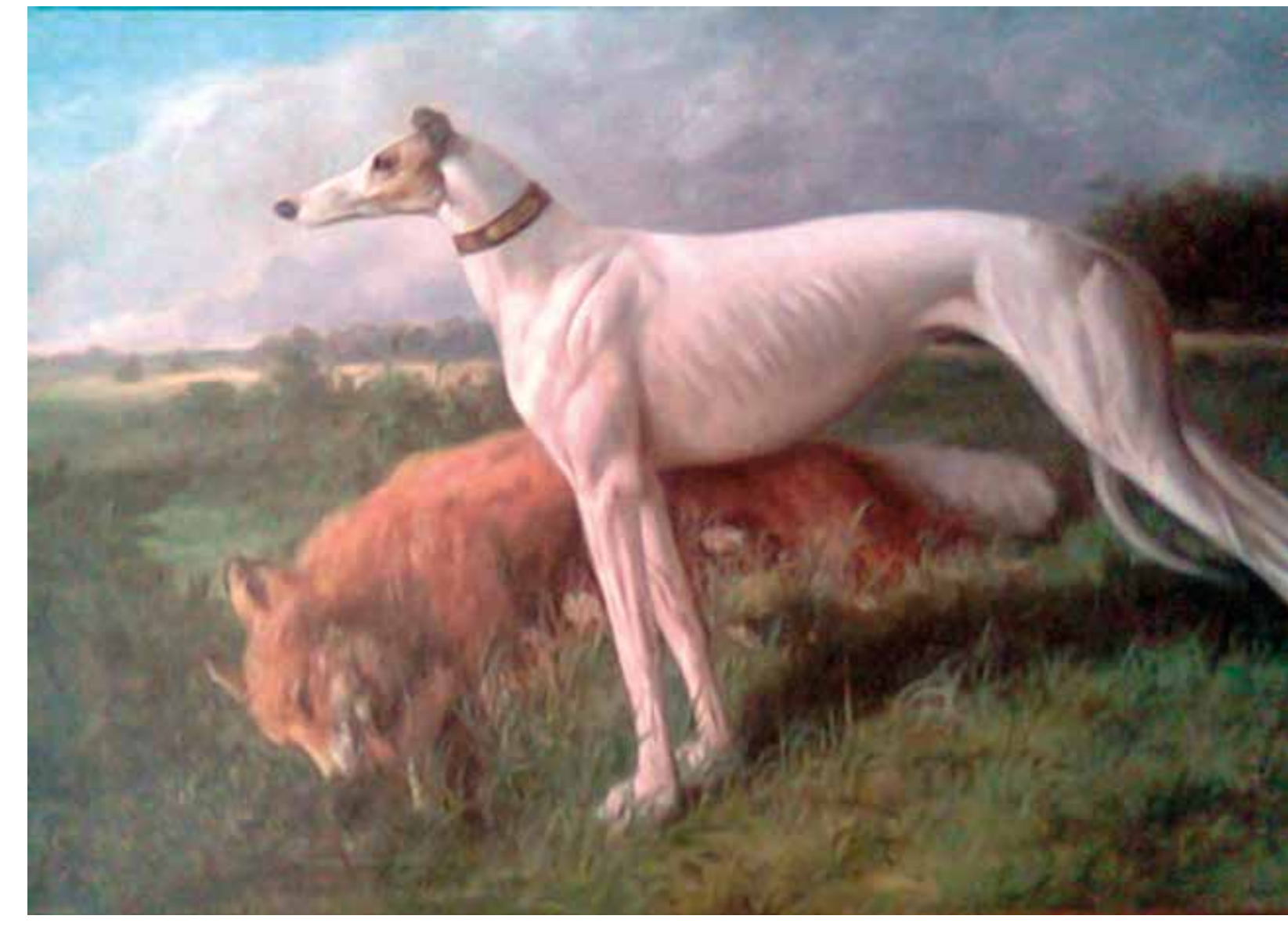

III. 1. N. E. Sverchko. A greyhound dog with a fox. X, M, 1890. GRM

master, secondly, significant in the universal sense, as problems of the safety of all life on earth, which led to the formulation of the problem of the relationship "nature-man". These two interrelated as pects, that were predetermined by the epoch, are significant in the sense of comprehending the specifics of the animal painting genre, which left high artistic standards in the heritage.

The methodology of the research is the theoretical analysis of the problem in the historical context of two eras. Letters, memories of the artists served as the basis for consistent consideration of this issue.

The basic worldview and artistic principles

Let's consider the points of view of artists-animalists on the wildlife world of the 19th and 20th century, of the man's perception of nature was changed cardinally, its role and meaning in the humans society, values of the alive creature.

Let's pay attention to the fact that the hunting theme takes a big spot in the Russian genre painting of the 19th century. It became widespread in the XVIII century, then the paintings of the relevant subjects in the XIX century acquired a new artistic expression. The interest in this topic is explained by its popularity in Russian society since tsarist times. In the second half - the end of the 19th century in the era of Alexander II and then Pavel I, along with the imperial hunt, there were provincial ones, farms, using commercial animals, were developing fast. At the same time, besides the type of trade which ensures the vital activity of man and asserts his superiority over nature, the hunt continued to be the same attribute of life as secular balls and military parades. A large edition of N. I. Kutepov: "The Grand Ducal Tsar Hunt in Russia from the 10th to the 16th Century" [Kutepov 1896:211], "The Tsar Hunt in Russia of the Tsars Mikhail Fedorovich and Alexei Mikhailovich of the 17th Century" [Kutepov 1898: 315] "The Imperial Hunt in Russia the end of the 18th and the 19th century" [Kutepov, 1911: 328] was considered as a bright fact

The hunting as a hobby had let to a wide variety of works in which the "hunting" animals wer taking a central place, they were seen by artists in the realization of their hunting characteristics and in the indispensable natural environment. It is worth to remember the paintings by N. E. Sverchkov, P. P. Sokolov, R. F. Frents, A. D. Kivshenko, sculptures by A. L. Ober, E. A. Lanceray (Fig. 1,2,3)
Images of national scenes - Russian provincia hunts determined the thematic range of their works, within which ones the masters found a variety of plot options. A large place was taken by the image of hunting dogs - Russian borzoi. Their popularity was caused by the fact that in the 19th century people looked at this as an advantage if they took dogs to the hunt too, which ones consisted mainly of greyhounds and hounds. N. Kutepov in his historical essay describing the imperial hunt in Russia of the end of the 18th-19th centuries, noted that as dogs for hunting, which replaced the tsar's hunting birds (falcons, golden eagles, hawks, peregrine falcons, saker falcons), along with hounds and greyhounds were used dogs of other breeds: "Medellan, Moscow water dog and English setters, but in a small number (...). The "cop dogs" that were kept by chasseurs and poultry houses were also belonged to that list.(...) Dogs, that were the property of the emperor, empress, heir-tsarevich and some of the grand dukes, were kept on special grounds. (...) Good dogs were bought at landowners, among which ones there were a lot of passionate hunters》 [Kutepov, 1911: 328].

In the "hunts" of painters there are a lot of "royal", grandeur and pomp, greyhounds with their beautifu outlines backed up with their expressive aristocratic appearance. Their movements are graceful, bodies are rhythmic. Here, certainly, the poetic interpretation of the animal can be read. However, there was barely someone who thought about a moral side of it. The «hunt» wasn't considered from the moral side at those times. People weren't used to talk about the damage they brought to the wildlife and the feelings experienced by animals in stressful situations. A. L. Ober, sculptor-animalist, wrote about it in his works. For example: «In France, if there is law, then a positive one, the hunt is strictly organized, the foresters serve the fields and forests. A a certain time only the right to hunt is given only for a well-known fowl and strictly defined but the right for a hunt for a deer was very expensive, and the hunter is allowed to kill only a certain number of deers. It's a well-known fact that it's a very cruel kind of pleasure. On the eve of the planned hun people choose a potential victim and, in the morning, when the red-fesco hunters gathered on horseback, the deer gets frightened from the spot and a desperate chase begins, followed by a dozen of toothed dogs, a true pursuit for the innocent animal for life and death, but the animal, exhausted suffering from ever-increasing fear and exhaustion is finally caught and not just by one, but dozens of dogs as a triumph over a defenseless animal! The nimal is slaughtered $n$ and one of the most beautiful ladies will probably receive deer's legs and the whole a triumphing crowd, full of emotions, with a cheerful and full of happiness laugh. is filling the stomaches up with such a nice dinner. There is no end for stories about adventures, but is there at least a drop of the pity for defenseless creature? Do they even understand?». The sculptor continues the thought: «Nature could exist forever in its wildness, in its poetic setting. I like the hunters' innocent glances - "looks like there is no more fowl and fish but recently there was way more". And they don't want to recognize, that just like their predecessors, they are ready to exterminate everything like predators just with the intention of their wishes satisfac tion. Evil rock is coming to replace the Divine wild harmony of nature. in all its inexhaustible origina beauty, and bringing destruction of all alive creatures. But does the people get any better? Everyone knows by the history of humanity how much blood is spilled» [Ober, 1917].

The epoch of the 20th century, indicated by the exacerbation of global problem, has brought the new vision of the world, of flora and fauna. In the dialog of human and nature artist-animalist stands on the side of nature. This conclusion is explained not only by the field what masters work in but also by their deep conviction, that more and more finds a feedback in the scientific community, - about the need in the dialogue of human and wildlife at the new level. In the first half of the 20th century, the human interest in research led to the fact that the boundaries of interaction between man and nature are becoming ever closer, and understanding of an animal is becoming more personal and specific, nature appears permeated with thought and experience. In the 20th century "The theory of" related attention " by M. Prishvin becomes popular not accidentally. It implies a depth of penetration into the lives of animals, birds and plants, which have their own unique "fate", their place in the universe. An imals, just like people, are endowed with personality traits. The admiration for the beauty of the anima world and its understanding brings us to a high moral sense»

In a process of affirmation of the significance of animalistic art, the world of wildlife, wild animals, organizing their lives independently of man, an im- 
portant role for masters and researchers belonged to science, which in the first half of the 20th century was directed on the active exploration of them. It's important to note that animalists V. Vatagin, V. Smirin, N. Kondakov had professional knowledge in the field of biology, were collaborating with the Darwinian Museum in Moscow for many years, performing an extensive series of illustrations on the themes of zoology, zoopsychology. Other artists, not having a biological education, comprehended the lives of animals and birds by intuitive means and artistic instinct, everywhere observed and studied nature.

The problem was that the animal appeared in front of scientists and artists eyes as a multifaceted creature. Researchers and artists found value in the interpretation of various manifestations of the life of animals, primarily wild: free, strong, independent. Their views on the value of nature and animals in it played a certain role. Among all of the classes, types of the animal kingdom, sculptors often gave their priority to the image of a mammal with bright natural plastic properties. For the first time, a biologist and an artist in one person concentrated their efforts on the solution of a complex task is the interpretation of the mental characteristics of wild animals and birds by means of art. The interest was cause by the mood of society and changes that were happening in people's minds looking at nature and animals not from a consumer point of view (as a source of satisfaction of their needs), but from the standpoint of knowledge and understanding of this world. In this connection, the view of the 20th century animalists on the world of nature, which are based on ethical and aesthetic ideas, has its own characteristic. In the relationship of human and nature, animal painters mark a dramatic moment. They see nature suffering, as the universal "drama of the organic macrocosm." In letters, on the pages of magazines, they talk about the destiny of wildlife and animals. Let's consider the statements that eloquently characterize the way of thinking of the artist-animalist of the 20th century. The heartfelt, sympathetic attitude to the world of nature is expressed in the words of B. Vorobiev. Talking about nature reserves as a certain preserved piece of the original world, he comes to disappointing conclusions: «The fate of all reserves looks pathetic (...) I'm afraid that even in this century many species of creatures will be eliminated. We leave a very poor inheritance for our following generations. There will be less and less people who are close to nature looking a true inspiration and consolation in it but, after all, many material "benefits", that are acquired by humanity, are not able to compensate the losses inflicted on the world by these acquisitions, because stomachs acquire more than souls.» [Vorobiev, 1959-60]. In the letter to V. Vatagin, D. Gorlov frankly admits: «It is necessary to communicate with animals and birds, dear to my heart, in order to reach a human condition.(...) Animal is way nobler, more sincere and less cunning than human [Gorlov, 1960-68].

Underlining the great significance role, which an mals have played in the development of civilization V. Vatagin sees the animal world under the sign of ry-historical tragedy and drama of the organic macrocosm: «No animal will torture or kill its victim in vain. What a destructive role, howeve human plays sometimes regarding animals! What a huge bloody bill nature could ask human to pay off for a numerous many predatory exterminated beautiful species of animals created by it!» [Vatagin, 1957:170]. «And when they kill for fun, I always worry as if it's the loss of something very close, dear to me...» - the artist shares.

The meaning of the statements is to justify the historical role of animals in the development of civilization. Masters invariably affirm the idea that nature-animal-human is a complex, fluid, historically developing structure, where everything is tied up with each other like in the thinnest nervous organization. There can't be an impassable abyss between them as in anatomy, physiology, as in the processes happening in them. With the whole course of thei thoughts, they emphasize that without this world, the existence of human is probably impossible.

Vatagin, Gorlov, Efimov, Sparrow lived at that time, when the situation, bringing up the issues of the wildlife protection, caring attitude of human to it, took place in the society. That's why animalist reasonings on this topic are quite natural. As we've mentioned A. Ober was concerned about these questions, who also was talking about the value of nature, about the perfection of animals, their different personalities and spoke very negatively about the hunt. The sculptor condemned all sorts of hunting fun, he couldn't understand hunters who killed such a huge number of animals, who could see only combination of bones and body weight in an animal without any «spiritual manifestation» and only «alive objects for a hunting pleasure». Nevertheless, his reasoning about hunting had a private charac-

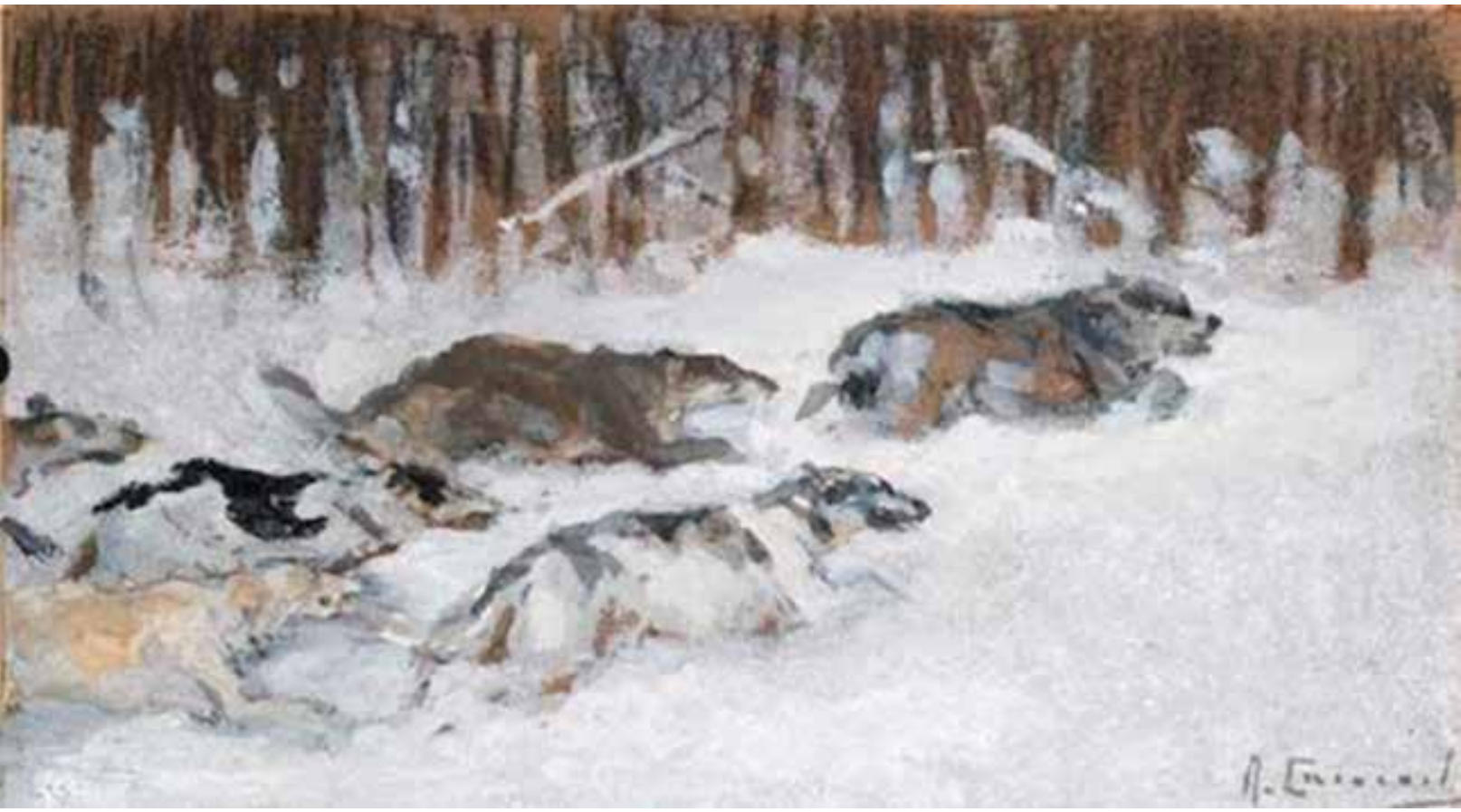

III. 2. A. S. Stepanov. Hounds of the 1910 s cardboard, tempera, timing

ter and wasn't a tendency exciting society, which, in general, did not prevent the sculptor from creating works depicting hunting and fighting animals, filled with strong tension and expression.

The works of animalists of the 20th century were different. Let's explain their interest in ancient cultures. Masters highlight the Ancient East. In their opinion, there animal was in high esteem. V. A. Vatagin was impressed by the art of ancient Egypt D. V. Gorlov, I. S. Efimov - by folk art, which determined their creative pursuit a lot $V$ Vatagin points at the significant place that animals had been taking in the ancient art. The art of Assyria, China, Egyp was consonant with the ideals of the artist. On the example of many works and masterpieces, he saw a picture of the human-animal relationship, which impressed him. The animal as a "divine creature "[Ryabinin, 1972:372], was a vivid expression in ancient Egyptian and Assyrian animalistic. An animal-hero in the images of the mighty bull, the lion is enclosed in the widely generalized, expressive forms of monumental-decorative art. The master was impressed by the ornamental art of the Scythians, where the animal in the weaves of a decorative composition is turned almost into a heraldic sign and with its conventional and at the same time really recognizable forms exudes a certain magical power. Artists also observed great interest in animals in the folk art. Animals and birds were an integral part of human life. Animalistic images, which are inherently con- ditional and very primitive, contain valuable qualty - spirituality. Animals were filled up with the thoughts, feelings, mood of humans, they were the organic whole with them.

In his memoirs I. Efimov draws attention to the works of art of the peoples of the East, as well as to the monuments of Russian folk art, which, in his opinion, «are examples of the truly high, forever inspiring art» [Efimov, 1977:423]. It is exactly where the sculptor feels the natural foundations of the animalistic image. D. Gorlov is also tend to rely on folk art. In the letter to E. N. Vataginoy He clearly defines his direction: «My foundation was the nature and folk art.» [Gorlov 1960-e].

About these cultures and the role of animals in them narrated by many authors. Bria Sex [Boria Sax 2001:298], Simon Lewis, Lloyd Llewellyn-Jones [Boria Sax, 2001:298], talk about the importance of understanding animals for modern man. They cover a wide range of time, focusing on the ancient culcance of the sacred animals of dynastic Egypt, as Vatagin wrote. Paul Waldau, Kimberley Christine Patton Waldau Paul, Kimberley Patton, 2009:686] noted that animals were present in all the religions of the world and reflects religious rituals, presenting a whole system of beliefs, myths. Their study contributes to a deeper understanding of human society as a whole. 


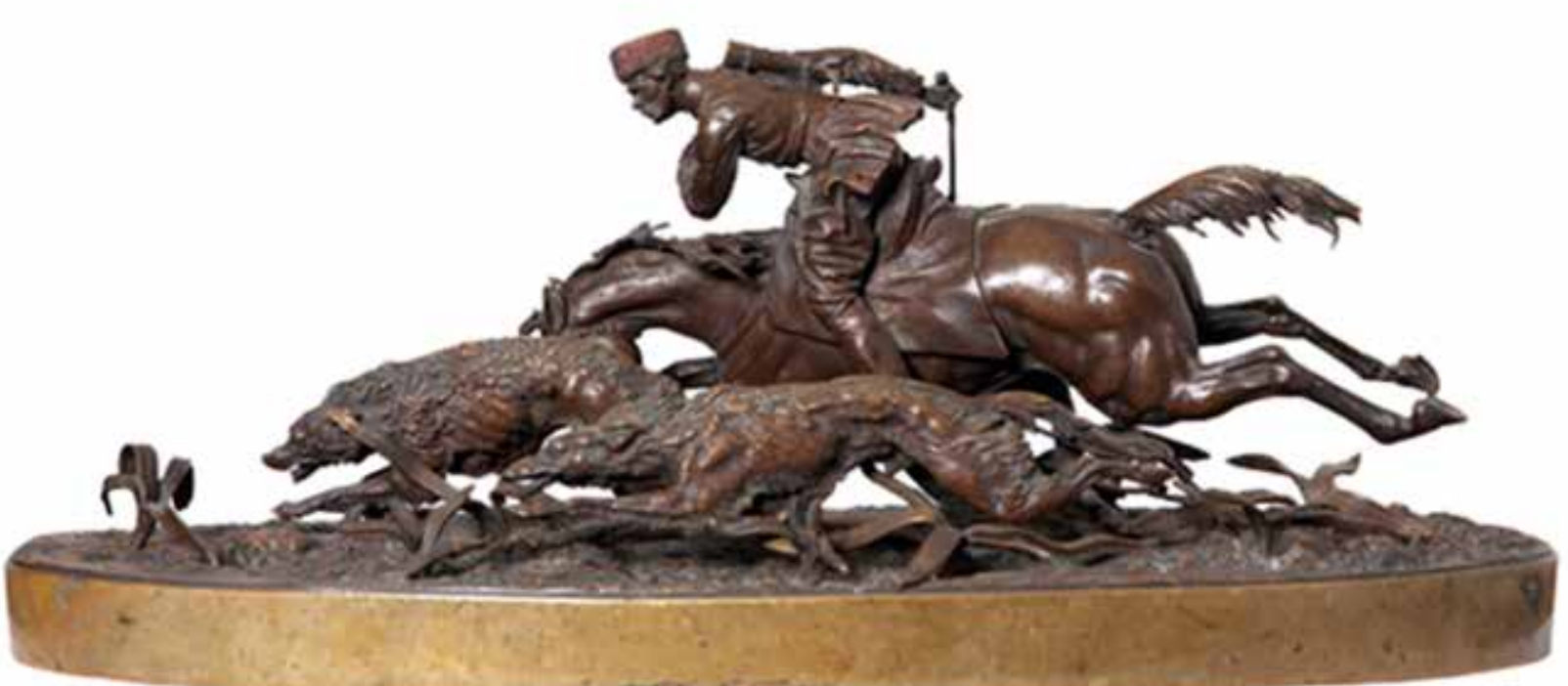

III. 3. N. I. Liberikh Hunting with greyhounds, bronze

The selection of precisely these periods in the development of animal painting is caused by the views of artists on the animal world and the painting skills. The symbolic perception of the image, a certain conventionality of the pictorial language these qualities impose the attitude of the artists. In sense of worldview in terms of modernity, the animalistic image of the past is highly relevant. The meaning of the animalistic art of the 20th century lies in the fact that it could most fully recreate the panorama of the natural world, associated in a broad sense with «the picture of the world». In the 20th century, a look at the world of nature and art, easel graphics, sculpture and painting, monumental-decrative works, plastic of small forms are the essence of one artistic concept of masters. It's a conception of a philosophical attitude. Art works acquire a multifaceted character. We can trace in them a variety of different shades of one theme, unexpected creative solutions, including traditions and styles of past eras. We don't even have to talk about genre boundaries. The modern animalistic art, brightly demonstrating a variety of pictorial plastic options, keeps on reflecting environmental theme, which in the modern world is becoming even more relevant In modern animalistic art, that branch of is important, which studies the general laws of interaction between animate and inanimate nature, in particuar, the problems of the influence of modern civilization on the world in general. loving and worshiping the world of living nature, their adherence to the traditions of ancient art, in which the animal was often depicted, as well as professional knowledge, all together defined the creative face of the painter-animalist of the 20th century, who is oriented on the demand of time In their statements, the animal painters revealed a holistic picture of the relationship between nature and man, the place of man in this world. Their opinions, judgments, teachings are interesting and useful for both as specialists, as a wide audience. On this path, speaking in its own independent genre quality, as a modality of a new thematic reality, the genre beginning of which found an expression in various types of fine art, it played an undoubted role in the broad world outlook as a value factor in the interaction of nature man and narrower as the visual theme of time.

The theme of nature and animals keeps on bring relevant in our time, besides, the educational aspect all for children and young people.

Acknowledgments. This paper has been sup ported by The RUDN University Strategic Academic Leadership Program on Soviet animal sculptors, Moscow, p. 238

Vatagin, V. A. 1980. Memils, Notes of an animalist. A-

4. Efimov, I. S. 1977. About art and artists. Moscow p. 423

9. Kutepov, N. 1898. Imperial hunting in Russia of tsars

In conclusion, we note that the ideological principles of artists-animalists, based on understanding
1. Tikhanova, V. A. 1990. The face of living nature.Essays ticles. Moscow, p. 213

3. Vatagin, V. 1957. A. The image of an animal: notes of an animalist. Moscow. p. 170 5. Caspari Elizabeth. 2003. Animal Life In Nature, Myth and Dreams. Chiron Publications, p. 350

6. Peterson Anna. 2013. Being Animal: Beasts and Boundaries in Nature Ethics, Columbia University Press, p. 236

7. Hurn, Samantha. 2012. Humans and Other Animals: Cross-Cultural Perspectives on Human-Animal, Pluto Press, p. 266

8. Kutepov, N. 1896. Grand Duke Royal hunting in Russia from X to XVI century. Historical essay. SPb.: The expedition of storing state papers. Edition. 2. vol. 1-3, p. 211 Mikhail Fedorovich and Alexey Mikhaylovich of XVII century. Historical sketch: Saint-Petersburg. Edition 2, vol. 2, p. 315

St. Petersburg: Expedition of preparation of state papers, p.328 RGALI. F. 1956. Op. 2. Ed. HR. 13

12. Letter Vorob'eva, V. A. Vataginu V. 1959-60s., RGALI. 3022. Op.1. Ed. HR. One hundred three,

3. Letters Gorlov D.V. Vatagin VA 1960-68., RGALI. F. 3022 Op.1. Ed. HR.One hundred seven.

14. Letter Gorlova DAY.Vatagina (with mention of Vatagina). 1960's, RGALI. F. 3022. Op. 1. Ed. HR. 191

15. Sax, Boria. 2001. The Mythical Zoo: An Encyclopedia of Animals in World Myth, Legend, and Literature. ABC CLIO, p. 298

16. Lewis, Sian, Lloyd, Llewellyn-Jones. 2018. The Culture of Animals in Antiquity: A Sourcebook with Commen taries. Routledge, London, p. 778

17. Waldau, Paul, Kimberley Patton. 2009. A Communion of Subjects: Animals in Religion, Science, and Ethics, $\mathrm{Co}$ lumbia University Press, p. 686

10. Kutepov, N. 1911. Imperial hunting in Russia of the end of XVIII and XIX centuries. Historical essay, vol. 4.
B. S. 1972. Zeropanic Vatagin. Looking at life. Sverdlovsk, Sredne-Uralsky Book Publishing House, p. 372. 
Ирина Васильевна Портнова

Доцент департамента архитектуры

инженерной академии

Российского университета дружбы народов

e-mail: irinaportnova@mail.ru

Москва, Россия

ORCID ID: 0000-0002-9064-5288

DOI: 10.36340/2071-6818-2021-17-4-49-61

\section{РУССКОЕ АНИМАЛИСТИЧЕСКОЕ ИСКУССТВО XIX-XX BEKOB ВО ВЗГЛЯДАХ НА МИР ФЛОРЫ И ФАУНЫ}

Аннотация: Статья освещает взгляды художников-аималистов XIX-ХХ веков на мир живой природы. Мирогоззренческие вопросы во многом предопределёноисторической ситуацией, рассматриваются как ценностнй фактор взаимосвязи человека и мира живой прирой фактор взаимасвяи чолеркваеся незаменимая роль животного разиитии человеческой цивилизации. Отсюда следуе этическое отношение к природе как уникальной ценности. Отмечается, что нравственно-этическая основа этих

взаимоотношений, ставшая актуальной в эпоху глобаль-

\section{Введение}

В XX веке в связи с обострённым восприятием мира живой природы весьма актуальными становятся рассуждения на тему взаимоотношений человека и животных, что привело к стремлению более глубоко проанализировать наследие художников-анималистов. В этом отношении можно отметить статьи В. А. Тихановой [Тиханова, 1990: 238], которые носят характер художественно-критических очерков. Они важны постановкой проблемы, тесно связанной с нравственно-этической оценкой, вытекающей из самой сути творчества художника-анималиста. Автор отмечает, что в многообразии выразительных средств и приёмов, к которым обращаются художники XX века, ясно звучит концепция сохранности живой природы, соотносимая с задачами анималистического искусства на современном этапе. На эту же тему рассуждал художник-анималист В. Ватагин на страницах своего мемуарного труда «Воспоминания. Записки анималиста» [Ватагин, 1980: 213], в ос нову которого были положены материалы бо лее раннего издания «Изображение животного ных перемен и кризиса экологической ситуации, способствовала формированию экологического мишления как реальности Нового времени В мировоззрении художника-анималиста животное выгларит красивии хего поведение целесообразным, оказывающим благотворное влияние на человека. Рассматривается взаимосворвзгядов художника и видение им анималистического

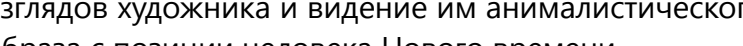

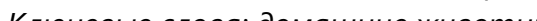

нные, идеология природа, экология.

[Ватагин, 1957: 170]. Труд Ватагина и вышедшая в 1977 году книга И. С. Ефимова «Об искусстве и художниках» [Ефимов, 1977: 323] содержат художественно-теоретические взгляды мастеров на мир живой природы и искусство анималистики методы работы в скульптуре и графике. Так, яс ное изложение точек зрения художников на мир животных и искусство их изображения (особенно последовательное у Ватагина), позволяет выявить их систему ценностей и идеалов, которые оказываются весьма актуальными в эпоху постановки глобальных экологических проблем.

Исследователи нашего времени говорят о новых моральных стандартах в отношении живой природы. Если в старых культурах животное всегда включалось в область мифа, фольклора, челове ческих мыслей и мечтаний, было символичным что отражалось на уровне коллективного и инди видуального разума [Caspari Elizabeth, 2003: 350] то в эпоху технологических революций наблюдалась определённая напряжённость между людьми и животными, непонимание самой сущности живой природы [Peterson Anna, 2013: 236]. Саман- та Хурн [Samantha Hurn, 2012: 266] говорит о необходимости развития в наши дни экотуризма.

Актуальность статьи определяется необходимостью изучения мировоззренческих принципов творчества художников-анималистов, во-первых выступающих основой творческого замысла мастера, во-вторых, значимых в общечеловеческом смысле, как задачи сохранности всего живого на земле, обусловившей постановку проблемы взаимосвязи «природа - человек». Эти два взаимосвязанных аспекта, предопределённые эпохой, являются значимыми и в смысле постижения специфики жанра анималистики, который оставил в наследие высокие в художественном отношении образцы.

Методологией исследования выступает теоретический анализ рассматриваемой проблемы в историческом контексте двух эпох.

Основные мировоззренческие и художественные принципы

взгляды художников-анима стов на мир живой природы XIX и XX столетий, тех исторических периодов, когда кардинальным образом поменялось восприятие человеком при роды, её роли и значения в человеческом обществе, ценности самого живого существа.

Отметим, что в русской жанровой живопиcи XIX века большое место занимает тема охоты. Широкое распространение она получила в XVIII веке, затем картины соответствующей тематики в XIX столетии приобрели новое художественное воплощение. Интерес к данной теме объясняется её популярностью в русском обществе ещё с царских времен. Во второй полови не - конце XIX века в эпоху Александра II, а затем Павла I наряду с императорскими охотами имели место провинциальные, широким ходом шло развитие хозяйств, использующих промысловых животных. Одновременно из промысла, обеспечи вающего жизнедеятельность человека и утверждающего его превосходство над природой, охота продолжала быть таким же атрибутом жизни, как светские балы и военные парады. Как яркий факт увлечения охотным занятием ещё с царских вре мён выступило большое издание Н. И. Кутепова: «Великокняжеская царская охота на Руси с X по XVI век» [Кутепов, 1896: 211], «Царская охота на Руси царей Михаила Фёдоровича и Алексея Михайловича. XVII век» [Кутепов, 1898: 315], «Импе раторская охота на Руси. Конец XVIII и XIX век» [Кутепов, 1911: 328].
Увлечение охотой породило большое разнообразие произведений, в которых «охотничьи животные занимали центральное место, виделись художниками в реализации их охотничьих признаков и в непременном природном окружении. Стоит вспомнить картины Н. Е. Сверчкова, П. П. Соколова, Р. Ф. Френца, А. Д. Кившенко, скульптуры А. Л. Обера, Е. А. Лансере (рис. 1, 2, 3).

Изображения национальных сцен - русских провинциальных охот определяли тематический круг их произведений, в границах которых мастера находили разнообразные сюжетные вари анты. Большое место отводилось изображению охотничьих собак - русских псовых борзых. Их популярность объяснялась тем, что в XIX веке преимуществом пользовались псовые охоты, которые состояли главным образом из борзых и гончих собак. Н. Кутепов в историческом очерке, опи сывающем императорскую охоту в России конца XVIII-XIX веков, отмечал, что в псовой охоте пришедшей на смену царской с ловчими птицами (соколами, беркутами, ястребами, сапсанами, балобанами), наряду с гончими и борзыми использовались собаки и других пород: «меделянские водолазы, духовые и сеттера, но в незначительном числе (..). Принадлежали еще легавые собаки, которые содержались егерями, егерскими учени ками и птичниками. (...) При особых основаниях содержались собаки, составляющие собствен ность Императора. Императрицы, Наследника Цесаревича и некоторых Великих Князей. (...) Хорошие собаки покупались у помещиков, среди которых было немало страстных охотников» [Кутепов, 1911: 328]

В «охотах» живописцев много «царского», величия и пышности, борзые красивого очертания запечатлены в своём выразительном аристократическом облике. Их движения изящнь тела ритмичны. Здесь, безусловно, прочитыва ется поэтическая трактовка животного. Однако мало кому в голову приходила мысль о моральной стороне дела. С нравственных позиций в то время «охоты» не рассматривались. Не принято было говорить об ущербе, которые они наносили дикой природе, и о тех чувствованиях, которые испытывали животные, оказавшиеся в стрессовых ситуациях. В своих воспоминаниях об этом красноречиво писал скульптор-анималист А. Л. Обер. Приведём его показательные рассуждения: «Во Франции если есть закон, то положительный, охота строго организована, обслуживают поля и леса 
лесничие. В известное время только на известную дичь даётся право на охоту строго опреде лённое, но на охоту оленя продаётся любителю очень дорого, да и владетелю позволяется уби вать только известное количество оленей. Всем известно это донельзя безжалостное удовольствие. Праздным радостным кавалерам и нежным дамам, упражняющимся в этой спортивной охоте. Накануне намечается логовище намеченного зверя, а на утро при собравшихся верхами красно-фрачных охотников олень спугивается с места и начинается отчаянная гоньба, за ним с помощью десятка зубастых собак, гоньба по истине только для невинного зверя не на жизнь, а на смерть, но вот зверь, измученный, настрадавшийся от все усиливающегося страха и утомления, наконец схвачен и не одним, а десятками псов как торжество над беззащитным зверем Зверь зарезан и какой-то из прелестнейших дам преподносятся оленьи ноги и вся торжествующая толпа, раскрасневшаяся, разгоревшаяся с полным смехом и радости торжества наполняют свои истощенные желудки наисытнейшим и весёлым обедом. Рассказам о приключениях нет конца всё до крайних мелочей вспоминается, но в сердцах христианнейших победителей есть ли места хоть проблеску жалости к беззащитному существу, да и поймут ли они?» Скульптор продолжае мысль: «Природа в своей дикой бытности могла бы существовать бесконечно в своей поэтической обстановке. Мне нравятся наивные взгляды охотников, что «что-то нет больше дичи и рыбы, а сперва столько её водилось. И не хотят сознаться, что как и их предшественники, так и они готовы всё хищнически истребить, лишь бы только им теперь поохотиться или поживиться во всю сласть. Злой рок ведёт на замену Божественной дикой гармонии природы во всей её неисчерпаемой оригинальной красоте и несёт истребление всего живого. Но сытнее ли становится от этого народ, каждый знает по истории людей, сколько крови пролито» [Обер, 1917].

Эпоха XX века, обозначенная обострением глобальных проблем, привнесла новое видение мира флоры и фауны. В диалоге человека с природой художник-анималист стоит на стороне природы. Данное умозаключение объясняется не только родом занятий мастеров, но и их глубинным убеждением, всё больше и больше находящим отклик в научной среде,- о необходимости диалога человека с живой природой на новом уровне.
Исследовательский интерес человека в первой половине XX века привёл к тому, что границы взаимодействия между человеком и природой становятся всё более тесными, а пониман вотного всё более личностным и конкретным, природа предстаёт пронизанной мыслью и переживаниями. Не случайно в XX веке «получае распространение теория «родственного внимания» М. Пришвина которая подразумевает глубину проникновения в жизнь зверей, птиц и растений, у которых своя неповторимая «судьба», своё место во Вселенной. Животные, как и люди, наде ляются чертами индивидуальности. Восхищение красотой животного мира и понимание её рождает высокое нравственное чувство».

В процессе утверждения значимости анималистического искусства, самого мира живой природы, диких зверей, организующих свою жизнь независимо от человека, немаловажная роль для мастеров и исследователей принадлежала науке, которая в первой половине XX века была направлена на их активное изучение. Важно отметить, что анималисты В. Ватагин, В. Смирин, Н. Кондаков обладали профессиональными знаниями в области биологии, много лет сотрудничали с Дарви новским музеем в Москве, выполняя обширный цикл иллюстраций на темы зоологии, зоопсихологии. Другие художники, не имея биологическо го образования, постигали жизнь зверей и птиц интуитивным путём и художественным чутьём повсеместно наблюдали и изучали природу.

Проблема состояла в том, что животное предстало перед взором учёного, художника существом многогранным. Исследователи и художники находили ценность в интерпретации разных проявлений жизни зверей, прежде всего, диких свободных, сильных, независимых. Здесь сказались их взгляды на ценность природы и живот ных в ней. Среди всех классов, видов звериного царства скульпторы часто отдавали приорите образу млекопитающего, обладающего яркими природно-пластическими свойствами. Впервые биолог и художник в одном лице сконцентрировали свои усилия над решением сложной задачи - интерпретации психических особенностей диких зверей и птиц средствами искусства. Интерес был обусловлен настроениями в обществе теми изменениями, которые происходили в сознании человека, смотрящего на природу и жи вотных не с потребительской точки зрения (как источник удовлетворения своих нужд), а с по- зиций познания и понимания этого мира. В этой Связи характерен взгляд художников-анималистов XX века на мир живой природы, которые базируются на этических эстетических представлениях Во взаимоотношениях человека с природой анималисты отмечают драматический момент. Они видят природу страдающей, как всеобщую «драму органического макрокосмоса». В письмах, на страницах журналов они рассуждают о судьбе живой природы, животных. Приведём эти высказывания, которые красноречиво характеризуют мышление художника-анималиста XX столетия. Проникновенное, участливое отношение к миру природы выражено в словах Б. Воробьёва. Ведя разговор о заповедниках, как некой сохрани шейся частице первозданного мира, он приходит к неутешительным выводам: «Жалкой представ ляется судьба всех заповедников (...) боюсь, что ещё в этом столетии будут уничтожены многие виды существ. Неважное наследство мы оставляем нашим поколениям. Будет всё меньше людей, близких природе, ищущих в ней подлинного вдохновения и утешения, а ведь многие матери альные «блага», приобретаемые человечеством не в состоянии возместить потерь, наносимых миру этими приобретениями, ибо приобретают больше желудки, но не души» [Воробьев, 1959 1960]. В письме В. Ватагину Д. Горлов откровенно признаётся: «Необходимо пообщаться с милыми моему сердцу зверями и птицами, чтобы прийти в человеческое состояние ( ) Зверь куда благороднео, искреннее и менее коварен, чем человек» [Горлов, 1960-1968].

Подчёркивая то огромное значение, которое сыграли животные в развитии цивилизации В. Ватагин видит животный мир под знаком эволюционно-исторической трагедии и драмы органического макрокосма: «Никакой зверь не станет мучить или понапрасну убивать свою жертву. Какую, однако, иногда истребительную роль играет человек по отношению к животным! Какой огромный кровавый счёт могла бы предвя человеку природа за множество хищнически истреблённых прекрасных видов животных, соз данных ею!» [Ватагин В. А., 1957: 170]. «И когда убивают ради удовольствия, я всегда переживаю как потерю чего-то очень близкого, дорогого...» - говорит художник.

Смысл высказываний заключается в обосновании исторической роли животных в развитии цивилизации. Мастерами неизменно утвержда- ется мысль о том, что природа - животное человек - сложная, подвижная, исторически развивающаяся структура, где всё взаимосвязано, как в тончайшей нервной организации. Не может быть непроходимой пропасти между ними, как в отношении анатомии, физиологии, так и процессов в них происходящих. Всем ходом своих мыслей они подчёркивают, что без этого мира навряд ли возможно само существование человека.

Ватагин, Горлов, Ефимов, Воробьёв жили в то время, когда в обществе имела место ситуация затрагивающая вопросы сохранности живой при роды, бережного отношения человека к ней. Поэтому рассуждения анималистов на эту тему вполне закономерны. Как мы заметили, эти вопросы волновали А. Обера, который также говорил о ценности природы, о совершенстве животных, их разных индивидуальностях и весьма негативно высказывался об охоте. Скульптор осуждал всякие охотничьи забавы, от рук которых гибнет большое количество зверей, не понимал охотников, видящих в животном только сочетание костей и массы тела без «духовного проявления» и только «живые механизмы для охотничьего удовольствия». Все же его рассуждения об охоте имели частный характер и не были тенденцией, волнующей общество, что, в общем, не мешало скульптору создавать произведения с изображением охотящихся и борющихся зверей, исполненные сильного напряжения и экспрессии.

Другим было творчество анималистов XX столетия. Объясним их интерес к древним культурам. Мастера выделяют Древний Восток. По их мнению, там животное было в почёте. В. А. Ватагин впечат лялся искусством Древнего Египта, Д. В. Горлов, И. С. Ефимов - народным творчеством, которые во многом определяли их творческие искания. В. Ватагин указывает на значительное место, отводимое животному в древнем искусстве. Искус ство Ассирии, Китая, Египта созвучно идеалам художника. На примере многих произведений он увидел картину взаимоотношений человекживотное, которая импонировала ему. Живот ное как «зверобожество» [Рябинин, 1972: 372] явилось ярким выражением в древнеегипетской и ассирийской анималистике. Зверь-герой в образах могучего быка, льва заключён в широко обобщённые, выразительные формы монументально-декоративного искусства. Мастера впечатляло орнаментальное искусство скифов, где 
животное в переплетениях декоративной композиции превращено почти в геральдический знак и своими условными и одновременно реально узнаваемыми формами источает некую магическую силу. В народном искусстве художники также наблюдали большой интерес к животным. Звери и птицы были неотъемлемой частью человеческой жизни. Анималистические изображения по своей сути условные и весьма примитивные, содержали ценное качество - одухотворённость. Животные одухотворялись мыслями, чувствами настроением человека, они были едины с ним.

В своих воспоминаниях И. Ефимов обращает внимание читателя на произведения искусства народов Востока, а также на памятники русского народного творчества, которые, по его мнению, «являют собой образцы действительно высокого, вечно вдохновляющего искусства» [Ефимов, 1977: 423]. Именно здесь скульптор ощущае природные основы анималистического образа Д. Горлов также склонен опираться на народное творчество. В письме Е. Н. Ватагиной он чётко определяет свою направленность: «Моей основой основ была природа и народное искусство» [Горлов, 1960-е].

Об этих культурах и о роли животных в них повествовали многие авторы. Boria Sax [Boria Sax 2001: 298], Sian Lewis, Lloyd Llewellyn-Jones [Boria Sax, 2001: 298] говорят о важности понимания животных для современного человека. Они охватывают широкий диапазон времени, сосредотачиваясь на древних культурах Средиземноморья а также значимости священных животных династи ческого Египта, о чём писал Ватагин. Waldau Paul, Kimberley Patton [Waldau Paul, Kimberley Patton 2009: 686] отмечали, что животные присутствовали во всех мировых религиях и отражали религиозные ритуалы, представляя целые системь верований, мифов. Их изучение способствует более глубокому пониманию человеческого соци ума в целом.

Выделение именно этих периодов в развитии анималистики обусловлено взглядами художни ков на мир животных, на самое мастерство изо бражения. Символическое восприятие образа определённая условность изобразительного языка - эти качества импонируют мироощущению художников. В мировоззренческом плане в ракурсе современности анималистический образ прошлого весьма актуален. Значение же анимали стического искусства XX столетия в том и состоит, что оно полнее всего смогло воссоздать панораму природного мира, ассоциируемого в широком смысле с «картиной мира». В XX веке взгля на мир природы и искусство, станковая графика, скульптура и живопись, монументально-декоративные работы, пластика малых форм - суть грани одной художественной концепции мастеров. Эта концепция философского настроя. Художественные произведения приобретают многоликий характер. В них можно проследить столько разных оттенков одной темы, неожиданных творческих решений, включающих традиции и стиле вые направления прошлых эпох. Здесь говорить о видовых и даже жанровых границах не приходится. Современное анималистическое искусство ярко демонстрирующее разнообразные изобразительно-пластические варианты, продолжае отражать экологическую тему, которая в современном мире становится ещё более актуально значимой. В современном анималистическом ис кусстве оказывается важной та отрасль биологии которая изучает общие закономерности взаимодействия живой и неживой природы, в частности, проблемы влияния современной цивилизации на окружающий мир.

\section{Заключение}

В заключение отметим, что мировоззренческие принципы художников-анималистов, основанные на понимании, любви и преклонении перед миром живой природы, их приверженност к традициям древнего искусства, в котором часто изображалось животное, а также професси ональные знания, в совокупности определили творческое лицо художника-анималиста XX века, ориентированного на запросы времени. В своих высказываниях анималисты раскрыли целостную картину взаимосвязи природа - человек места человека в этом мире. Их взгляды, сужде ния, учения представляют интерес и полезны как для специалистов, так и для широкой ауди тории. На этом пути, выступив в своём самостоятельном жанровом качестве, как модальность новой тематической реальности, жанровое начало которой нашло выражение в разных видах изобразительного искусства, оно сыграло несомненную роль в широком мировоззренческом смысле как ценностный фактор взаимодействия природы-человека и более узком как изобразительная тема времени

Тема природы и животных продолжает быть актуальной в наше время, к тому же воспита- тельно-образовательный аспект анималистики очевиден для всех поколений, прежде всего, для детской и юношеской аудитории.

Подтверждения. Статья написана в рамках Программы стратегического академического лидерства РУДН.

БИБЛИОГРАФИЯ

1. Тиханова В.А. Лик живой природы: Очерки о советских скульпторах-анималистах.—Москва: Советский художник, 1990.- 238 с.

2. Ватагин В.А. Воспоминания. Записки анималиста Статьи. -Москва: Советский художник, 1980. - 213

3. Ватагин В.А. Изображение животного: Записки анималиста. -Москва: Искусство, 1957. - 170 с.

4. Ефимов И.С. Об искусстве и художниках.-Москва: Советский художник, 1997.- 423 с.

5. Caspari Elizabeth. Animal Life In Nature, Myth and Dreams. - Chiron Publications, 2003. - $350 \mathrm{p}$.

6. Peterson Anna. Being Animal: Beasts and Boundaries in Nature Ethics. - Columbia University Press, 2013.$236 \mathrm{p}$

7. Hurn Samantha. Humans and Other Animals: CrossCultural Perspectives on Human-Animal__-Pluto Press, 2012.-266 p.

8. Кутепов Н. Великокняжеская царская охота на Руси с X по XVI век: Исторический очерк // Экспедиция заготовления государственных бумаг_- Издание 2.-Т. 1-3.-С.-Петербург, 1896.- 211 с.

9. Кутепов Н. Царская охота на Руси царей Михаила Фёдоровича и Алексея Михайловича. XVII век: Исторический очерк - Издание 2-Т 2-С--Петербург, $1898 .-315$ c
10. Кутепов Н. Императорская охота на Руси конца XVII и XIX веков: Исторический очерк // Экспедиция заготовления государственных бумаг.-Т. 4. - С.-Пе-

ия. Май 1917 г. // РГАЛИ. Ф. 1956. Оп. 2. Ед. хр. 13

B. A. $1959-1960$ // РГАЛИ. Ф. 3022. Оп. 1. Ед. хр. 103.

13. Письма Горлова Д.В. Ватагину В.А. 1960-1968 // РГАЛИ. Ф. 3022. Оп. 1. Ед. хр. 107.

14. Письмо Горлова Д. Ватагиной Е.Н. (с упоминаниxp. 191

15. Sax Boria. The Mythical Zoo: An Encyclopedia of Animals in World Myth, Legend, and Literature.-ABC CLIO, 2001.- $298 \mathrm{p}$.

16. Lewis Sian, Lloyd Llewellyn-Jones. The Culture of Animals in Antiquity: A Sourcebook with Commentaries. Routledge. - London, 2018. - $778 \mathrm{p}$

17. Waldau Paul, Kimberley Patton. A Communion of Subjects: Animals in Religion, Science, and Ethics.Columbia University Press, 2009.-686 p.

18. Рябинин Б.С. Зверопоклонник Ватагин // Вглядываясь вжизн. -С ердлолск: Средне-Уральское книжное издательство, 1972. - 372 c. тербург, 1911. - 328 с 